\title{
Abundance and Distribution of Macroinvertebrates of the Affon River in Bénin
}

\author{
Olakonlé Serge Samon1, Fadéby Modeste Gouissi ${ }^{*}$, David Darius Adje1, Koudjodé Simon Abahi1, \\ Christelle Madina Tchaou', Jeff Gildas Antoine Okoya1, Zoulkanerou Orou Piami1, \\ Midogbo Pierre Gnohossou ${ }^{1}$, Gbenga Omoniyi ${ }^{2}$, Christophe Piscart ${ }^{2}$
}

\author{
${ }^{1}$ Department of Management of Natural Resources (AGRN), Water and Soil Engineering, Laboratory of Ecology, Health and \\ Animal Production (LESPA), Faculty of Agronomy (FA), University of Parakou (UP), Parakou, Benin \\ ${ }^{2}$ Univ Rennes, CNRS, ECOBIO UMR, Rennes, France \\ Email: ^gouissi@yahoo.fr
}

How to cite this paper: Samon, O.S., Gouissi, F.M., Adje, D.D., Abahi, K.S., Tchaou, C.M., Okoya, J.G.A., Orou Piami, Z., Gnohossou, M.P., Omoniyi, G. and Piscart, C. (2019) Abundance and Distribution of Macroinvertebrates of the Affon River in Bénin. Open Journal of Marine Science, 9, 173-187.

https://doi.org/10.4236/ojms.2019.94013

Received: August 17, 2019

Accepted: October 5, 2019

Published: October 8, 2019

Copyright $\odot 2019$ by author(s) and Scientific Research Publishing Inc. This work is licensed under the Creative Commons Attribution International License (CC BY 4.0).

http://creativecommons.org/licenses/by/4.0/

\section{cc) (i) Open Access}

\begin{abstract}
This study focuses on the biodiversity of macroinvertebrates of the Affon River. To reach this goal, eight stations were sampled and physical parameters such as temperature, $\mathrm{pH}$, conductivity, transparency, depth, total dissolved solids (TDS) and dissolved oxygen were measured. Chemical parameters such as ammonium nitrite and phosphate were measured in the laboratory. We identified 9755 macroinvertebrates belonging to 4 classes, 14 orders, and 49 families. Chironomidae were the most abundant family whereas other sensitive insect's orders such as Ephemeroptera, Trichoptera, and Plecoptera were rarely found, suggesting a poor water quality of the Affon River. The principal components analysis yielded three groups of stations: the first group (Tenéka 2 and 3) characterized by high values of ammonium and phosphate and low values of conductivity and TDS; the second group (Tanéka 1 and Kolokondé 1) with low values of $\mathrm{pH}$, transparency, ammonium and phosphate; and the third group of stations (Kolokondé 2, Kpébouko1, Kpébouko 2, and Affon) marked by high values of conductivity, TDS, transparency, depth and temperature. This study is a crucial step for any management and monitoring of the Affon River.
\end{abstract}

\section{Keywords}

West Africa, Freshwater, Water Quality, Monitoring

\section{Introduction}

Rivers are among the most complex and dynamic ecosystems [1]. They are extensively diversified and play a crucial role in the conservation of biodiversity. 
However, these ecosystems are severely degraded from the effects of urbanization, industrialization and agricultural intensification. These anthropogenic and natural disturbances have direct impacts on the diversity and structure of macroinvertebrates and necessitate the need for better management of the systems. An effective surface water quality assessment must take into account biological criteria throughout bioindicators [2] [3] such as diatoms, macrophytes, benthic macroinvertebrates and fish [4]. In recent times, benthic macroinvertebrate communities have been the most widely used bioindicator to assess the overall health status of aquatic ecosystems [5] largely because of their sedentary lifestyle, varied life cycles, high diversity and variable tolerance to pollution and habitat degradation [6]. Consequently, this study evaluated their richness, diversity and taxonomic composition to assess the effects of human activities on the water quality of the river Affon in Benin [6]. Indeed, in Benin, the structure, diversity, composition and faunal characteristics of macroinvertebrates have been analyzed in various ecosystems [5] [7]-[12], but knowledge on freshwater biodiversity in this country remains very scarce. These studies highlighted important biodiversity of macroinvertebrates of certain groups such as Diptera, Gastropods, Oligochaetes and Coleoptera in Benin freshwaters. The dominance of certain taxa is indicative of the degradation of the water quality in most studied ecosystems [9] [10]. This degradation of the water quality led to the disappearance of several taxa, especially those that are pollution-sensitive to the detriment of pollution-tolerant taxa [9] [10]. In addition, according to a recent study [13], parameters that influence the distribution of macroinvertebrates in Benin were mainly nitrate, phosphate, conductivity and TDS, whereas transparency and depth were also found as important factors in other studies [10]. Therefore, in order to contribute to the knowledge of the macroinvertebrate fauna in Benin and the environmental factors explaining their distribution, we studied the diversity and distribution of macroinvertebrates and the water quality of the Affon River.

\section{Materials and Methods}

\subsection{Study Area and Sampling Stations}

The Affon River is located on the right bank and in the classified forest of upper Ouémé. This river is one of the tributaries of the Ouémé River. It has a length of $152 \mathrm{~km}$ and a catchment area of $4320 \mathrm{~km}^{2}$. The river is located in the Sudano-Guinean zone and is under the influence of the tropical climate characterized by the succession in the year of a single rainy season from April to October and a single dry season from November to March, marked by the preponderance of the harmattan. On the Affon River, 08 stations were selected after prospecting. They were chosen based on the sustainability of the water, altitude, accessibility in all seasons, depth and speed of the water [14]. Table 1 shows the characteristics of these different stations.

\subsection{Measurement of Water Physico-Chemical Parameters}

At each station, the measurements of physical parameters (temperature, depth, 
Table 1. Location, geographic coordinates and characteristics of sampling stations.

\begin{tabular}{|c|c|c|c|c|}
\hline Stations & Codes & $\begin{array}{l}\text { Geographic } \\
\text { coordinates }\end{array}$ & Altitude & Pollution sources \\
\hline Tanéka-Koko1 & Tan1 & $\begin{array}{l}\text { N: } 09^{\circ} 51 ' 21^{\prime \prime} \\
\mathrm{E}: 01^{\circ} 32^{\prime} 34^{\prime \prime}\end{array}$ & $484 \mathrm{~m}$ & Artisanal extraction of gold \\
\hline Tanéka-Koko2 & Tan2 & $\begin{array}{l}\text { N: } 09^{\circ} 53^{\prime} 89^{\prime \prime} \\
\text { E: } 01^{\circ} 47^{\prime} 48^{\prime \prime}\end{array}$ & $429 \mathrm{~m}$ & Laundry, dishes, artisanal extraction of gold \\
\hline Tanéka-Koko3 & Tan3 & $\begin{array}{l}\text { N: } 09^{\circ} 52^{\prime} 40^{\prime \prime} \\
\text { E: } 01^{\circ} 30^{\prime} 80^{\prime \prime}\end{array}$ & $415 \mathrm{~m}$ & Laundry, dishes, artisanal extraction of gold \\
\hline Kolokondé1 & Kol1 & $\begin{array}{l}\text { N: } 09^{\circ} 53^{\prime} 94^{\prime \prime} \\
\text { E: } 01^{\circ} 47^{\prime} 44^{\prime \prime}\end{array}$ & $410 \mathrm{~m}$ & $\begin{array}{c}\text { Agricultural waste, washing of motorcycles } \\
\text { and laundry }\end{array}$ \\
\hline Kolokondé2 & Kol2 & $\begin{array}{l}\text { N: } 09^{\circ} 57^{\prime} 17^{\prime \prime} \\
\text { E: } 01^{\circ} 51^{\prime} 43^{\prime \prime}\end{array}$ & $369 \mathrm{~m}$ & $\begin{array}{l}\text { Household waste, agricultural waste, } \\
\text { washing of motorcycles and laundry }\end{array}$ \\
\hline Kpebouco1 & Kpe1 & $\begin{array}{l}\text { N: } 09^{\circ} 57^{\prime} 15^{\prime \prime} \\
\text { E: } 01^{\circ} 51^{\prime} 43^{\prime \prime}\end{array}$ & $365 \mathrm{~m}$ & Agricultural, household and livestock wastes \\
\hline Kpebouco2 & Kpe2 & $\begin{array}{l}\text { N: } 09^{\circ} 56^{\prime} 58^{\prime \prime} \\
\text { E: } 01^{\circ} 50^{\prime} 54^{\prime \prime}\end{array}$ & $363 \mathrm{~m}$ & Laundry, household and livestock waste \\
\hline Affon & Aff & $\begin{array}{l}\text { N: } 09^{\circ} 57^{\prime} 46^{\prime \prime} \\
\text { E: } 01^{\circ} 51^{\prime} 78^{\prime \prime}\end{array}$ & $348 \mathrm{~m}$ & $\begin{array}{c}\text { Watering cattle, washing of motorcycles and } \\
\text { laundry }\end{array}$ \\
\hline
\end{tabular}

transparency, TDS, conductivity, $\mathrm{pH}$, oxygen) were carried out in situ very early in the morning between 08:00 and 12:00, before the sampling of the macroinvertebrates to avoid any disturbance of the environment. The water temperature, TDS and conductivity were determined using a portable conductivity meter (HANNA HI 99300). The $\mathrm{pH}$ was measured with a portable $\mathrm{pH}$ meter (HANNA HI 98107). A Secchi disk with a graduated rope was used to measure the transparency of the water and the depth of the stations. Water samples were made at each station in $500 \mathrm{ml}$ plastic bottles decontaminated and stored in a cooler containing ice for transport to the laboratory for analysis of the dissolved substances. The determination of the concentration of dissolved elements of the water samples was carried out in the Laboratory of Hygiene, Sanitation, Ecotoxicology and Environmental Health (HECOTES) using a spectrophotometer DR 6000. Chemical parameters such as ammonium, nitrite and phosphate were respectively measured by the Nessler method [15], the iron sulphate method and the Vanadomolybdic method with persulfate digestion.

\subsection{Sampling of Macroinvertebrates}

The benthic macroinvertebrates were sampled at the 08 stations. They were taken using a Surber sampler with a 500- $\mu \mathrm{m}$ mesh. This material was placed on the bottom of the river, the opening of the net facing watercourse and the substrate is scraped a few centimeters with the hand. Twelve samples with a unit area of $1 / 20 \mathrm{~m}^{2}$ were done per station: (08) eight on the dominant habitats and (04) on the marginal habitats as recommended by the standard IBGN and already used in the North of Benin by Abahi et al. (2018) [10]. The organisms collected in the 
surber sampler were spilled in labeled jars and fixed to $10 \%$ formaldehyde and then sent to the laboratory.

\subsection{Macroinvertebrates Identification}

In the laboratory, the captured macroinvertebrates were rinsed to rid them of the formalin and were subsequently sorted station by station under a binocular dissecting microscope. After sorting, they were grouped according to their class up to the family level apart from oligochaetes, nemathelmintes, hydracarians, hydrozoans, sponges, bryozoans and nemerteans which were kept aside such as Abahi et al. (2018) [10]. The taxonomic determination was made using the following keys: Benthic macroinvertebrates of the streams of "la Nouvelle-Calédonie" by Mary (2017) [16], Identification guide of the main benthic macroinvertebrates of freshwater from Quebec written by Moisan (2010) [17], "Freshwater invertebrates: Systematics, biology, ecology" by Tachet et al. (2000) [18] and "Aquatic entomology" by McCafferty (1981) [19] after which macroinvertebrates were enumerated and then stored in pillboxes containing $70 \%$ alcohol.

\subsection{Data interpretation}

The identified data allowed us to calculate the following metrics and indices:

Taxonomic richness $(S)=$ number of taxa present in each station

Abundance $(N)=$ number of individuals from a taxonomic group in each station

Relative abundance $(\mathrm{Nr})=$ ratio as a percentage of the number of taxon individuals in a station to the total number of individuals of all species from all stations.

Frequency of family observation $(F O)=\left(F_{i} \times 100\right) / F_{t}$ In such, $F_{i}=$ number of stations containing the family and $F_{t}=$ total number of stations studied. Three families were thus distinguished as Abahi et al. (2018) previously demonstrated. We have very frequent families ( $F \geq 50 \%)$, frequent families $(25 \% \leq F \leq 50 \%)$ and rare families $(F \geq 25 \%)$.

\subsection{Statistics Analysis of Data}

The data obtained were processed using Excel 2010 software and R3.4.4 software [20]. The taxonomic richness, the taxonomic abundance, the average values of the physico-chemical parameters were calculated per station. Parametric and non-parametric tests (test $\mathrm{t}$ student and test of Kruskal-Wallis) were used to evaluate the variability of the taxonomic richness of the abundance and diversity indices at the 5\% threshold with the R3.4.2 software [20]. Moreover, the factorial correspondence analysis (FCA) was used for grouping the stations according to the similarity association of macroinvertebrates families. In addition, a canonical correspondence analysis (CCA) was performed using PAST statistical package [21]. 


\section{Results}

\subsection{Physico-Chemical Quality of the Affon River Water}

\subsubsection{Water Quality of the Affon River}

The analyzed results of the physico-chemical parameters of the Affon River waters are shown in Table 2. It indicates that the lowest temperature value of $22.5^{\circ} \mathrm{C}$ was recorded at Tanéka 1 (upstream) and the highest $30.3^{\circ} \mathrm{C}$ at Kpébouco 2. Depth and transparency increased from upstream to downstream. Thus, the maximum values were measured at Tanéka 1 while the minimum values were recorded at the Affon. The $\mathrm{pH}$ ranged between 6.5 and 8.5, with the minimum value recorded at Tanéka 2 while the maximum value was observed at Tanéka 1 and Kolokondé 1 stations. As for the conductivity and the TDS, they presented the same trend with average values that increased overall from upstream to downstream. Conductivity values ranged from 6.3 to $98.0 \mu \mathrm{S} / \mathrm{cm}$ and TDS values ranged from 3.0 to $49.0 \mathrm{mg} / \mathrm{l}$. The low values of these parameters were recorded at Tanéka 2 and the high values at Affon. The low values of phosphates $(7.11 \mathrm{mg} / \mathrm{l})$ were recorded at Affon and the high values $(14.8 \mathrm{mg} / \mathrm{l})$ at Tanéka 2 while the high values of ammonium are recorded at Tanéka 3 (1.35 $\mathrm{mg} / \mathrm{l})$ and the low values are obtained at Képébouco $(0 \mathrm{mg} / \mathrm{l})$. The Affon River is free of any trace of nitrite. In general, all the physico-chemical parameters studied except ammonium, varied significantly between the stations.

\subsubsection{Typology of Stations}

An abiotic typology of the stations carried out using a principal component analysis (PCA) reveals that most of the information contained in the variables are controlled at $86.25 \%$ by the first two dimensions ( 1 and 2 ) (Figure 1 ). Temperature, conductivity, TDS, transparency, depth and ammonium contributed more to the formation of the first axis while $\mathrm{pH}$, phosphate and temperature are more related to the second axis. The correlation circle (Figure 2) indicates that ammonium $(r=-0.74 ; \mathrm{p}=0.03)$, temperature $(\mathrm{r}=0.78 ; \mathrm{p}=0.02)$, transparency $(\mathrm{r}=0.89 ; \mathrm{p}=0.002)$, depth $(\mathrm{r}=0.85 ; \mathrm{p}=0.007)$, conductivity and TDS $(\mathrm{r}=0.90$;

Table 2. Physico-chemical characteristics of the Affon River waters.

\begin{tabular}{cccccccccc}
\hline Stations & Tan1 & Tan2 & Tan3 & Kol1 & Kol2 & Kpe1 & Kpe2 & Aff & p \\
\hline Temperature & 22.5 & 23.3 & 25.6 & 24.0 & 26.7 & 25.1 & 30.3 & 29.5 & 0.00 \\
Conductivity & 56.0 & 6.3 & 13.3 & 57.3 & 45.3 & 56.0 & 51.3 & 98.0 & 0.00 \\
TDS & 28.0 & 3.0 & 6.7 & 28.7 & 22.7 & 28.0 & 25.7 & 49.0 & 0.00 \\
Transparency & 13.3 & 14.3 & 15.3 & 17.0 & 17.3 & 19.7 & 23.0 & 24.3 & 0.00 \\
pH & 6.5 & 8.5 & 7.5 & 6.5 & 7.7 & 7.7 & 8.1 & 8.0 & 0.00 \\
Depth & 13.3 & 15.3 & 17.0 & 17.3 & 26.7 & 28.3 & 30.0 & 32.7 & 0.00 \\
Nitrites & 0 & 0 & 0 & 0 & 0 & 0 & 0 & 0 & - \\
Ammonium & 0.06 & 0.97 & 1.35 & 0.04 & 0.06 & 0.18 & 0 & 0.09 & 0.10 \\
Phosphates & 7.58 & 14.8 & 10.3 & 7.5 & 8.55 & 14.29 & 7.74 & 7.11 & 0.00 \\
\hline
\end{tabular}


Variables factor map (PCA)

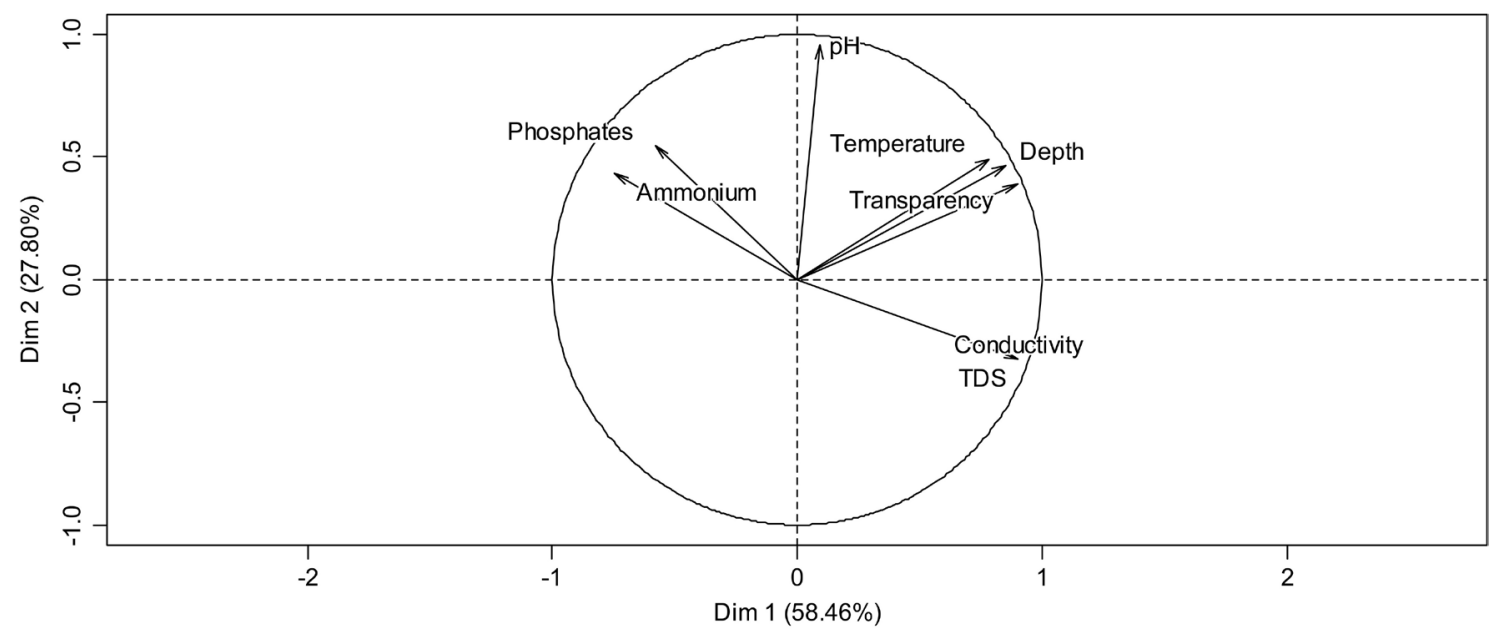

Figure 1. Positioning of the physico-chemical parameters on the axis.

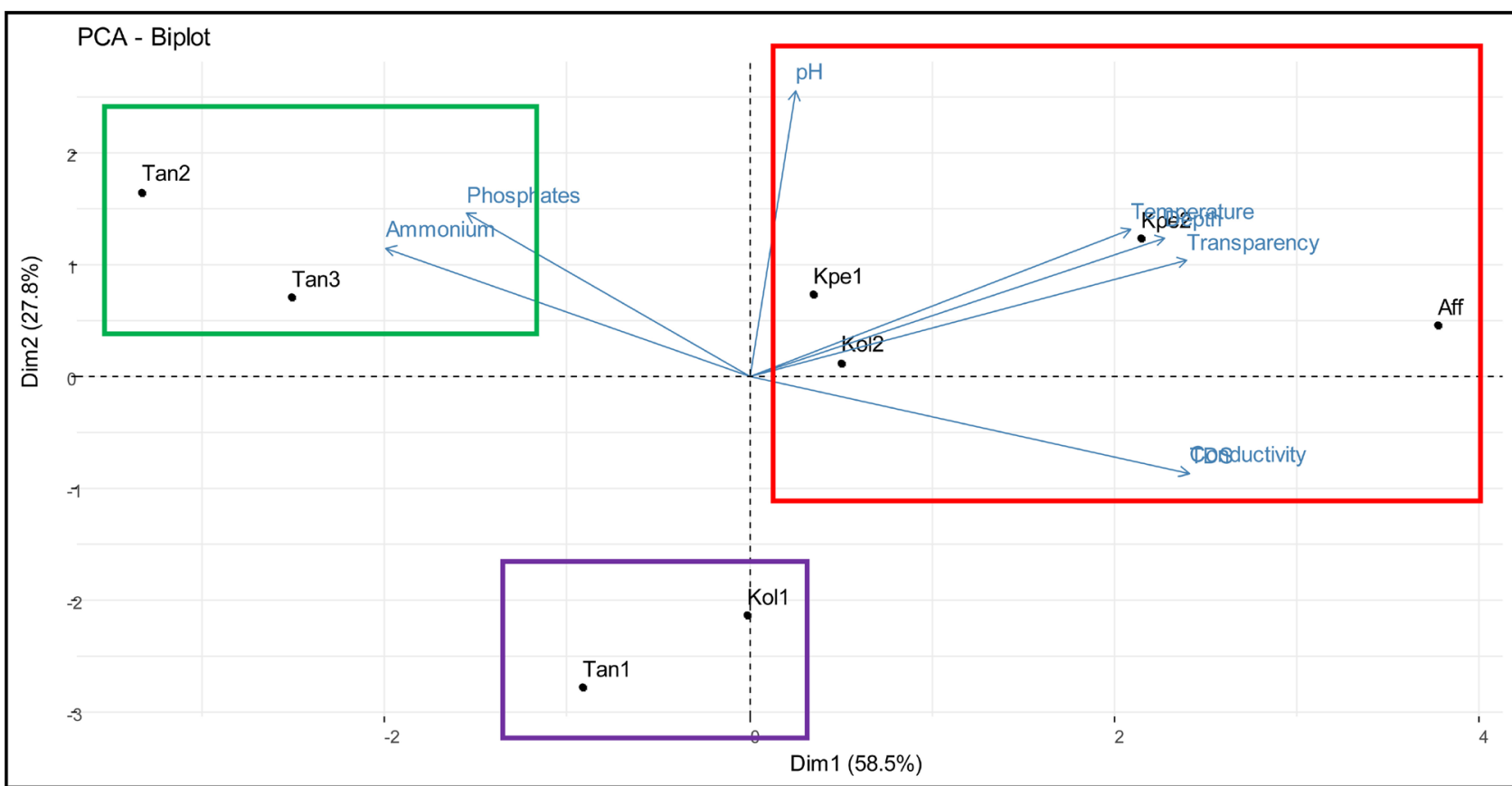

Figure 2. Distribution of physico-chemical parameters and stations.

$\mathrm{p}=0.002)$ are strongly and significantly correlated with dimension $1 . \mathrm{pH}(\mathrm{r}=$ $0.95 ; \mathrm{p}=0.0002)$ is strongly, positively and significantly correlated with dimension 2. Figure 3 on the distribution of parameters and stations allowed the stations to be grouped into three groups and to highlight the following associations: 1) the group of Tanéka 2 and Tanéka 3 stations characterized by high ammonium and phosphates; and low values of conductivity and TDS; 2) the group of Tanéka 1 and Kolokondé 1 stations with low $\mathrm{pH}$, transparency, ammonium and phosphates; and 3) the group of Kolokondé 2, Kpébouko1, Kpébouko 2 and Affon stations marked by high values of conductivity, TDS, transparency, depth and temperature. 


\subsection{Composition and Distribution of Macroinvertebrates}

\subsubsection{Abundance and Relative Abundance of Macroinvertebrates}

During the study, 9755 macroinvertebrate individuals were captured belonging to 49 families, 14 orders and 04 classes. Insects were the most dominant class of macrofauna with 9501 individuals or $97.40 \%$ of the total abundance (Figure 3). They were followed by worms (2.23\%), molluscs $(0.22 \%)$ and arachnids $(0.15 \%)$.

Among the fourteen orders, Diptera, made up of $76.90 \%$ of the total population, were the most dominant. Then come Trichoptera, Odonata and Ephemeroptera with $9.06 \% ; 5.06 \%$ and $4.25 \%$ of the total number of individuals harvested respectively. The remaining orders: Oligochaetes, Coleoptera, Heteroptera, Nemathelminthes, Gastropods, Hydracarina, Lepidoptera, Achaetes, Plecoptera and Hydracarians are the marginal communities with relative abundances lower than $02 \%$ (Figure 4 ).

Figure 5 shows the relative abundance of different families captured in the Affon River. It indicates that only one family, Chironomidae $(\mathrm{Nr}=73.17 \%)$ is

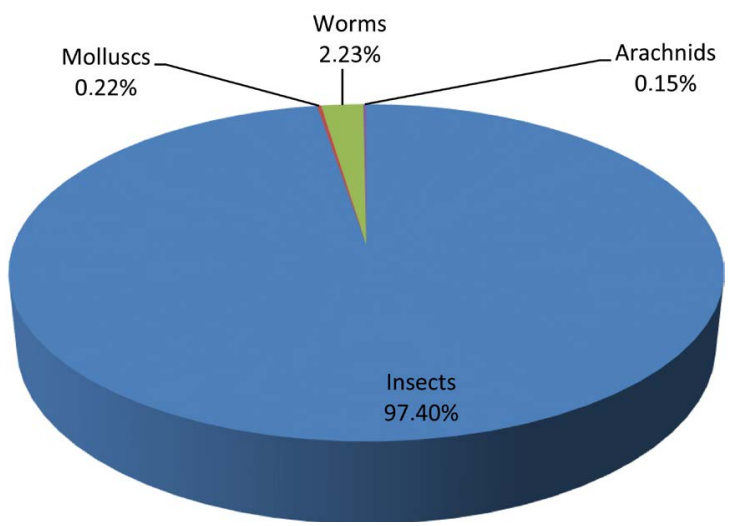

Figure 3. Relative abundance of taxonomic groups.

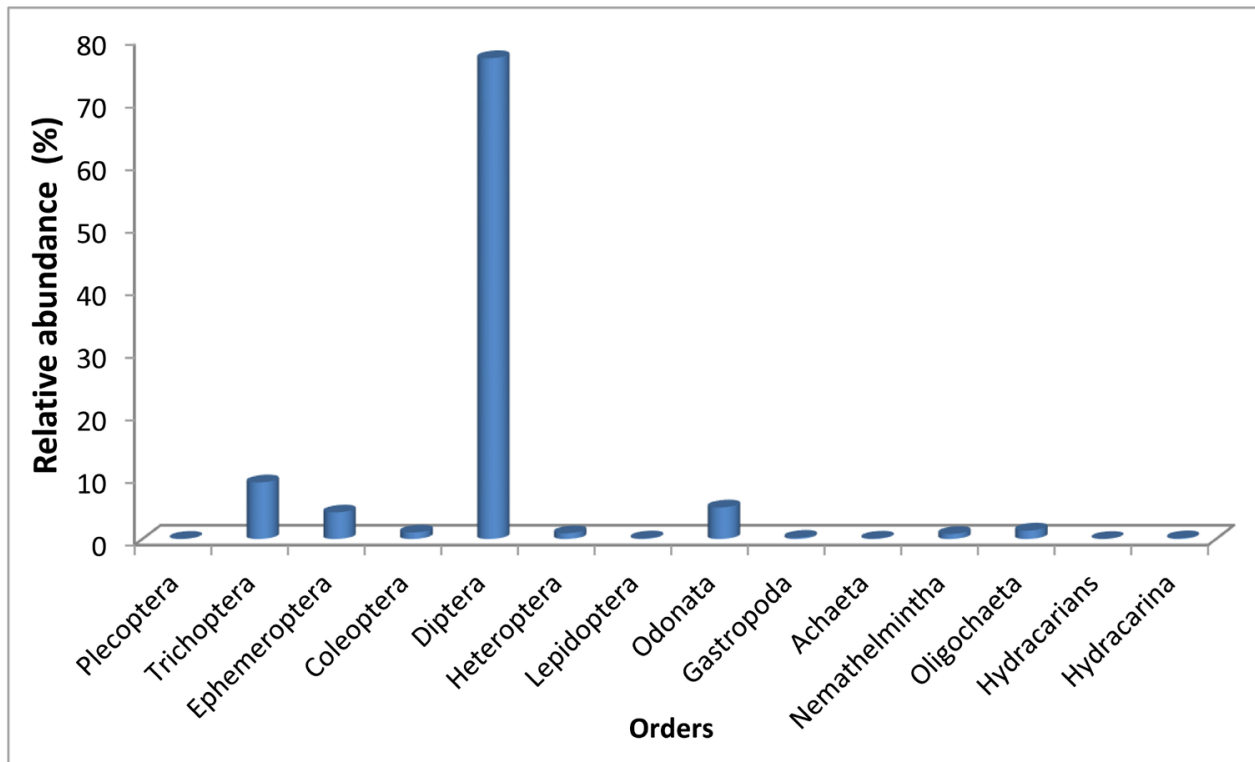

Figure 4. Relative abundance of macroinvertebrate orders. 


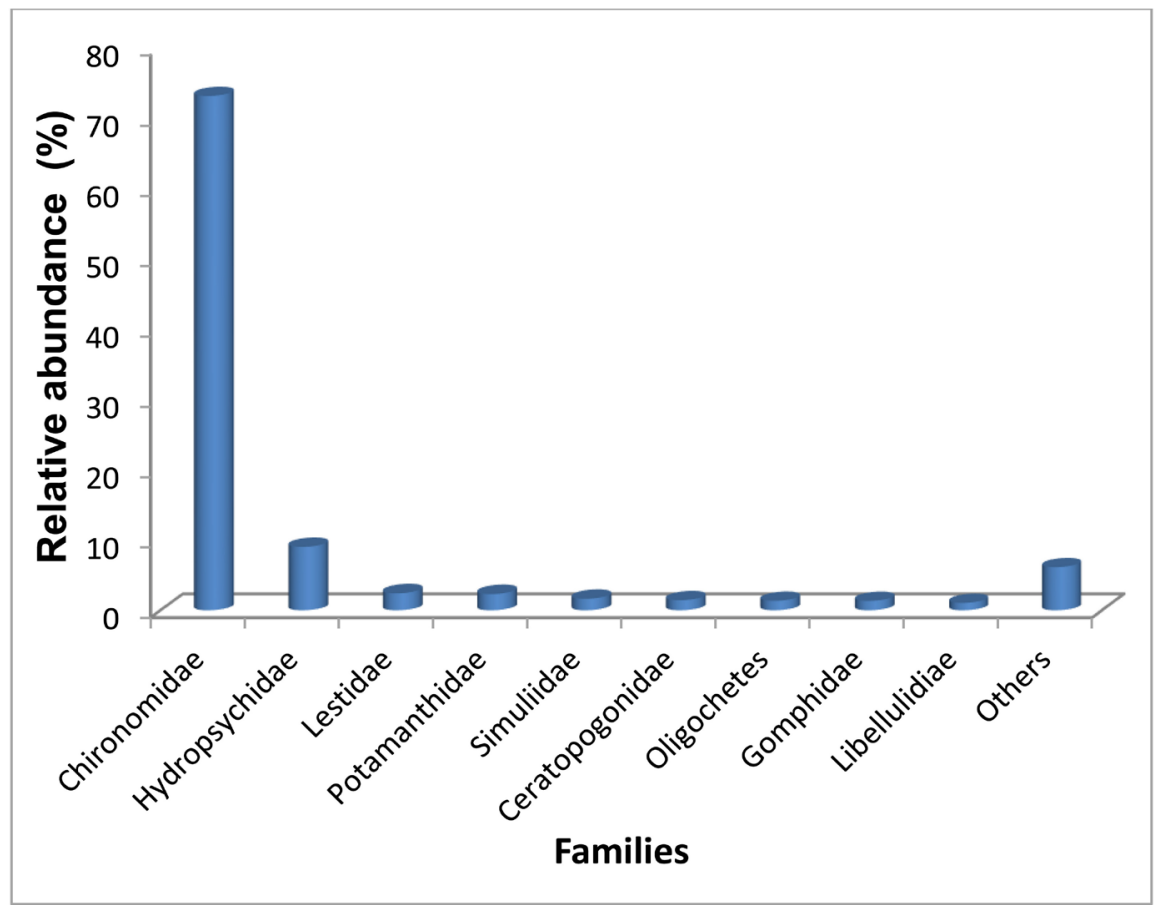

Figure 5. Relative abundance of macroinvertebrate families.

dominant in this watercourse, followed by Hydropsychidae $(\mathrm{Nr}=9.03 \%)$. About 95.92\% of captured families have a relative abundance of less than $3 \%$.

\subsubsection{Taxonomic Composition of Macroinvertebrate Classes \\ 1) Class of Insects}

The class of insects was very rich with 9501 individuals, 39 families and 08 orders. This class is dominated by Diptera containing 9 families and 7502 individuals, or $78.96 \%$ of the insect richness. They were followed by Trichoptera and Odonata with 2 families, 884 individuals; and 4 families, 494 individuals, thus constituting $9.30 \%$ and $5.20 \%$ of the insect richness respectively. Ephemeroptera, Coleoptera, Heteroptera, Lepidoptera and Plecoptera represent respectively $4.37 \% ; 1.07 \% ; 0.94 \%$ and $0.12 \% ; 0.04 \%$ of the insect richness.

\section{2) Class of Worms}

The worms are made up of three orders, namely the order of the Achetes (3.21\%), the order of the oligochaetes $(61.01 \%)$ and the order of the nemathelmintes (35.78\%).

\section{3) Class of Molluscs}

Molluscs consist of one order and 5 families, the most dominant of which are: Hydrobiidae (42.86\%) and Physidae (28.57\%). They are followed by Viviparidae (19.05\%), Limnaeidae and Bithynidae each constituting $4.76 \%$ of the mollusc richness.

\section{4) Class of Arachnids}

Hydracarians and Hydracarina are the two orders of captured Arachnids. Hydracarina accounts for $86.67 \%$ of arachnid richness compared with $13.33 \%$ for Hydracarians. 


\subsubsection{Evolution of Richness and Taxonomic Abundance per Station}

The highest taxonomic richness (30 families) was obtained at Tanéka 1 which is upstream while Tanéka 3 has the lowest taxonomic richness (6 families). As for the highest abundance, 2940 individuals or $30.14 \%$ of the total number of macroinvertebrates inventoried were obtained at Kolokondé 2 while Tanéka 3 was the station with the lowest abundance (43 individuals), or (0.44\%). In addition, values of richness and abundance showed significant differences between stations (Figure 6).

\subsubsection{Frequency of Occurrence of Macroinvertebrates}

Table 3 presents the frequency of occurrence of macroinvertebrate families. It shows that 19 families (38.78\%) are very frequent families while 9 families are frequent families (18.37\%). Finally, the 21 other families are rare families and constitute $42.85 \%$ of captured families. It is noted that only the Chironomidae

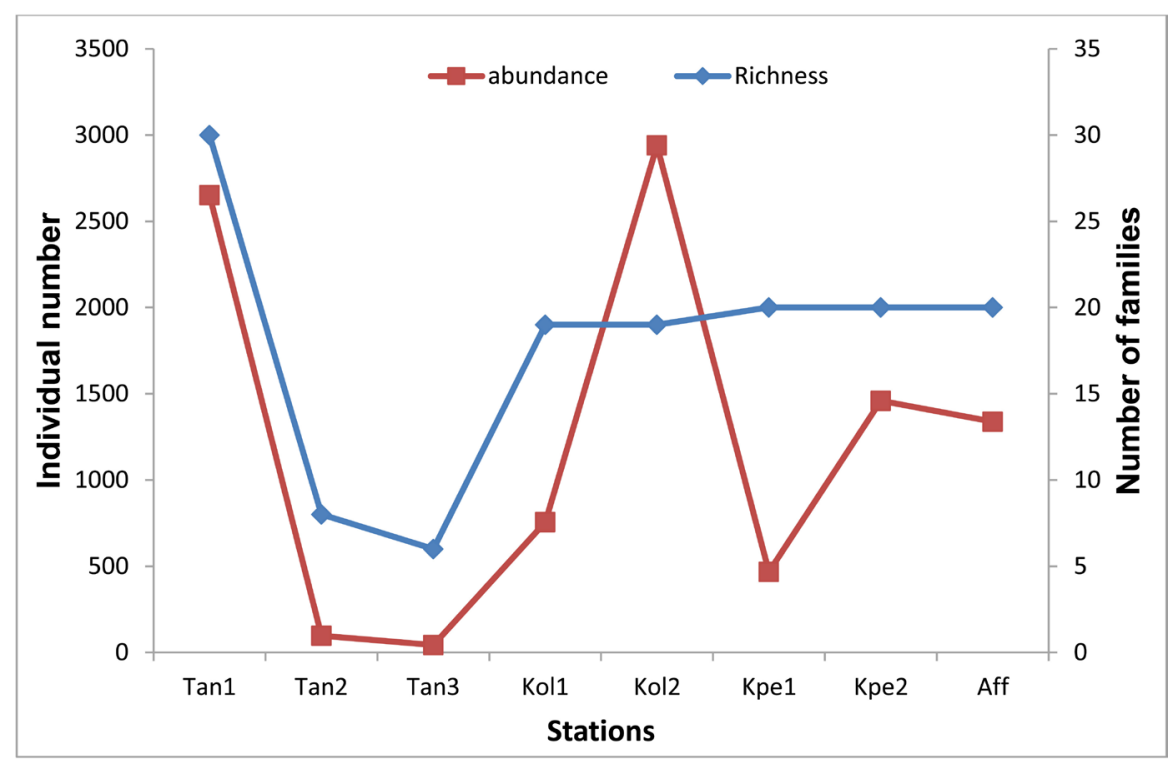

Figure 6. Spatial variation of taxonomic richness and abundance.

Table 3. Frequency of observation (FO) of macroinvertebrate families.

\begin{tabular}{|c|c|c|}
\hline $\begin{array}{l}\text { Very frequente families } \\
(\mathrm{F} \geq 50 \%)\end{array}$ & $\begin{array}{l}\text { Frequente families } \\
(50 \%>\mathrm{F} \geq 25 \%)\end{array}$ & Rares families $(\mathrm{F}<25 \%)$ \\
\hline Baetidae, Ephemerellidae & Hydrophilidae & Perlidae, Hydrobiidae \\
\hline Leptophlebiidae, Culicidae & Notonectidae & Nemouridae, Eubriidae \\
\hline Simuliidae, Gerridae & Pyralidae & Elmidae, Taeniopterygidae \\
\hline Veliidae, Araignées & Physidae & Leptoceridae, Nepidae \\
\hline Caenidae, Potamanthidae & Glossiphoniidae & Tabanidae, Bithynidae \\
\hline Hydropsychidae, Lestidae & Hydracariens & Ephemeridae, Isonychiidae, Viviparidae, \\
\hline Ceratopogonidae & Tipulidae & Limnaeidae, Heptageniidae, Sciomyzidae \\
\hline Corixidae, Libellulidiae & Aeschnidae & Chaoboridae, Tricorytidae, \\
\hline Oligochetes, Dytiscidae & Nemathelmintes & G \\
\hline Gomphidae, Chironomidae & & \\
\hline
\end{tabular}


family has a frequency of occurrence equal to $100 \%$.

\section{Discussion}

\subsection{Physico-Chemical Quality of Affon River}

The majority of physico-chemical parameters studied except phosphates and ammonium tend to follow an altitudinal zonation. Indeed, the average values of transparency, depth and temperature recorded on the stations of the Affon River are inversely proportional to the altitude. The recorded temperatures $\left(22.5^{\circ} \mathrm{C}\right.$ and $30.3^{\circ} \mathrm{C}$ ) are slightly higher than those obtained by Zinsou et al. (2016) [22]. Guigemde et al. (2003) [23] observed similar values for the Massili Basin in Burkina Faso $\left(18.6^{\circ} \mathrm{C}\right.$ to $\left.39.2^{\circ} \mathrm{C}\right)$. As for the water $\mathrm{pH}$ values, they are between 6.5 and 8.5 , perfectly within the tolerable limit ( 6.5 and 8.5 ) which characterizes aquatic life [24]. These results corroborate those recorded by Koudenoukpo et al. (2017) [25] on the Sô River in Benin and Buhungu et al. (2018) [26] on the Kinyankonge River in Burundi. The recorded conductivity and TDS values are in the range of reported values (59.8 and $238 \mu \mathrm{S} / \mathrm{cm}$ and 28 and $119.5 \mathrm{mg} / \mathrm{l}$ ) in the Ouémé delta [22]. These values are much lower than the values reported on the Sô River [25], but they are higher than those obtained on the Ogba River in Nigeria [27]. Mean values of conductivity and TDS increase with decreasing altitude and are within the range that characterizes natural water [24]. Regarding the values of nitrites, phosphates and ammonium, they do not follow a specific trend in relation to the altitude. The phosphate values recorded in this study (7.11 - $14.8 \mathrm{mg} / \mathrm{l})$ are higher than those for surface waters with an average value of $0.02 \mathrm{mg} / 1$ [28] [29]. These observed values classify the waters of Affon River in a general state that is bad with respect to their trophic state [30]. The phosphate values obtained in this water are much higher than those reported on the Ogba River in Nigeria [27] and on the Agnéby River in Côte d'Ivoire by Diomandé et al. (2009) [31]. Phosphate is the most limiting factor and the most important for aquatic productivity whose absence could lead to the depletion of aquatic ecosystems [32]. Conversely, high concentrations of phosphate can indicate the presence of pollution and are responsible for eutrophication conditions [28]. The recorded ammonium values are lower than the values reported by Zinsou et al. (2016) [22] in the Ouémé delta. Except for the value of Tanéka 3, the values recorded are below the standard set for surface water $(0.2 \mathrm{mg} / \mathrm{l})$ [28] and WHO, which is $0.5 \mathrm{mg} / \mathrm{l}$ for drinking water [33].

\subsection{Composition and Distribution of Macroinvertebrates}

The study has identified in the Affonriver, 9755 macroinvertebrates belonging to 49 families. The observed abundance is very low compared to that reported by Agblonon Houelome et al. (2017) [8] on the Alibori River (39,718). On the other hand, it is higher than that of the upper Ouémé River, where there were 3657 individuals of macroinvertebrate [10]. As for the taxonomic richness, it is identical to that reported on the Niger River [34] and on the Agnéby River in Côte 
d'Ivoire [31]. While it is much higher than that obtained by Abahi et al. (2018) [10] on the upper Ouémé River. The differences observed with the study by Abahi et al. (2018) [10] in the same area are due to the Surber sampler and the sampling period. In fact, during this study, we used the Surber sampler with a 500 micrometer mesh rainy season, while Abahi et al. (2018) [10] used the Surber sampler with a 100 micrometer mesh in low water. The diversity of the macroinvertebrate community harvested in the Affon River is marked by the importance of Diptera $(76.90 \%)$ dominated by the Chironomidae family which represent $73.17 \%$ of the total abundance. In Benin, the study conducted by Abahi et al. (2018) [10] on the upper Ouémé River, also revealed the predominance of Insects (85.23\%), Diptera (81.65\%) and Chironomidae (67.35\%). Similarly, in Burkina Faso, Sanogo et al. (2014) [35] and Kabré et al. (2000) [36] reported the dominance of Chironomidae in their studies. In addition, the study revealed the low diversity of pollution-sensitive orders (Ephemeroptera, Trichoptera and Plecoptera) both in terms of richness (14 families) and in terms of numbers (1,303 individuals), which would probably reflect the poor quality of the waters in the study area. These results, which are characteristic of rivers located in anthropized zones, corroborate well with the results obtained by (Abahi et al., 2018) [10] on the upper Ouémé River, by Imorou Toko et al. (2012) [9] in the Benin cotton basin and by OrouPiami (2018) [37] on the Sota River. Most encountered families are represented by only a few individuals. But Chironomidae (Diptera) are frequently and abundantly represented at all stations. Thus, the diversity of the Diptera Order observed and especially of the Chironomidae family reveals an accumulation of nutrients in the ecosystem; consequences of intense human activities [38] [39]. Anthropogenic activities near ecosystems disturb benthic communities and contribute to reduced species richness and even species distribution [35] [40]. In addition, the correlations established between families and the physicochemical parameters show a strong positive correlation between Nemouridae and ammonium on the one hand and between Perlidae, Taeniopterygidae, Ephemeridae, Heptageniidae, Isonychiidae, Elmidae and phosphate on the other hand, where there was a strong positive correlation. These correlations show the invulnerability of these families, which are mostly pollution-sensitive families, at the doses of phosphate and ammonium measured in this study.

\section{Conclusion}

The study of the water quality of Affon River reveals that the main physico-chemical parameters except phosphate have values that are relatively compatible with aquatic life. The absence of traces of nitrite in the watercourse supports good quality but is invalidated by the high levels of phosphorus compounds, responsible for the eutrophication of rivers. The present study inventoried 9755 macroinvertebrate individuals belonging to four classes, fourteen orders and forty-nine families. Insects were the most dominant with $97.40 \%$ of the 
total richness. Taxonomic richness and abundance tend to follow an altitudinal gradient. The analysis of the indices reveals an undiversified population and the environmental stress that this river undergoes. The strong positive correlations observed between Nemouridae and ammonium on the one hand and between Perlidae, Taeniopterygidae, Ephemeridae, Heptageniidae, Isonychiidae, Elmidae and phosphate show the invulnerability of these families, which are mostly pollution-sensitive families, at the doses of phosphate and ammonium measured in this study. Nevertheless, certain protection and recovery measures must be taken to preserve and improve the ecological status of the waters of Affon River. It involves the implementation of a sustainable river management plan, the promotion of organic farming, the awareness of the population on the importance of water and its quality. In addition, a long-term investigation based on biomonitoring and a sustainable management program are recommended to conserve the biodiversity of this river and develop a biotic index specific to the country.

\section{Acknowledgements}

We thank the people of our sampling places for their participation in the study. Special thanks go to the team of the Laboratory of Hygiene, Sanitary, Ecotoxicology and Environmental health (HECOTES) and the team of the Laboratory of Ecology, Health and Animal Production (LESPA).

\section{Conflicts of Interest}

The authors declare that they have no conflict of interest.

\section{References}

[1] Dynesius, M. and Nilson, C. (1994) Fragmentation and Flow Regulation of River Systems in the Northeast Third of the World. Science, 266, 753-762. https://doi.org/10.1126/science.266.5186.753

[2] Foto, M.S., Zebaze, T.S.H., Nyamsi, T.N.L., Ajeagah, G.A. and Njiné, T. (2011) Evolution Spatiale de la Diversité des Peuplements de Macroinvertébrés Benthiques dans un cours d'eau Anthropisé en Milieu Tropical (Cameroun). European Journal of Scientific Research, 55, 291-300.

[3] Foto, M.S., Tchakonté, S., Ajeagah, G.A., Zebaze, T.S.H., Bilong, B.C.F. and Njiné, T. (2013) Water Quality Assessment Using Benthic Macroinvertebrates in a Periurban Stream (Cameroon). International Journal of Biotechnology, 2, 91-104.

[4] Touzin, D. and Roy, M. (2008) Utilisation des macroinvertébrés benthiques pour évaluer la dégradation de la qualité de l'eau des rivières au Québec. Fac. Sci. L'agriculture L'alimentation Univ. Laval Quebec Can.

[5] Gnohossou, P. (2006) La faune benthique d'une lagune ouest Africaine (le lac Nokoue au Bénin), diversite, abondance, variations temporelles et spatiales, place dans la chaine trophique. Institut National Polytechnique de Toulouse.

[6] Moisan, J., Pelletier, L., Gagnon, E., Piedboeuf, N. and La Violette, N. (2013) Guide de surveillance biologique basée sur les macroinvertébrés benthiques d'eau douce du Québec, 2e ed. Direction du suivi de l'état de l'environnement.

[7] Zinsou, H.L., Gnohossou, P., Adandedjan, D. and Laleye, P. (2016) Profil de distri- 
bution des macroinvertébrés benthiques du delta de l'Ouémé à partir du Self Organizing Map (SOM). Scientific African, 12, 224-236.

[8] AgblononHouelome, T.M.A., Adandedjan, D., Chikou, A., ImorouToko, I., Koudenoukpo, C.Z., Youssao, I. and Laleye, P. (2017) Inventaire et caractéristiques faunistiques des macroinvertébrés de la rivière Alibori dans le bassin cotonnier du Bénin. International Journal of Innovation and Applied Studies, 21, 433-448.

[9] ImorouToko, I., Attakpa, E.Y., Gnohossou, P. and Aboudou, E.F. (2012) Biodiversité et structure des macroinvertébrés benthiques du bassin cotonnier béninois. Annales des Sciences Agronomiques, 16, 165-182.

[10] Abahi, K.S., Gnohossou, P., Akodogbo, H.H., OrouPiami, Z., Adje, D., Tchaou, C. and Okoya, J. (2018) Structure et diversité des macroinvertébrés benthiques de la partie supérieure du fleuve Ouémé au Bénin. Afrique Science: Revue Internationale des Sciences et Technologie, 14, 259-270.

[11] Odountan, H. and Abou, Y. (2016) Structure and Composition of Macroinvertebrates during Flood Period of the Nokoue Lake, Benin. Open Journal of Ecology, 6, 62. https://doi.org/10.4236/oje.2016.62007

[12] Adandedjan, D. (2012) Diversité et déterminisme des peuplements de macroinvertébrés benthiques de deux lagunes du Sud-Bénin: La Lagune de Porto-Novo et la Lagune Côtière. Thèse de Doctorat, Université d’Abomey-Calavi-Bénin, Bénin.

[13] Chikou, A., AgblononHouelome, T.M., Adandedjan, D., ImorouToko, I., Karim, I.Y.A. and Laleye, A.P. (2018) Structural Organization of the Macroinvertebrates Communities of the Alibori River during the Rainy Season (Northern Benin). International Journal of Fisheries and Aquatic Studies, 6, 285-291.

[14] Abahi, S. (2018) Les macroinvertébrés de l'Ouémé supérieur: Abondance, diversité et variation spatiale. Mémoire pour l'obtention du Diplôme de Master Recherche de l'Ecole Doctorale des Sciences Agronomiques et de l'eau de l'Université de Parakou, Bénin.

[15] APHA (1992) Standard Methods for the Examination of Water and Wastewater. 18th Edition, American Public Health Association (APHA), Washington DC.

[16] Mary, N. (2017) Les macroinvertébrés benthiques des cours d'eau de la Nouvelle-Calédonie. Guide d'identification. Version révisée 2017, DAVAR Nouvelle-Calédonie. ed, OEIL, CNRT.

[17] Moisan, J. (2010) Guide d'identification des principaux macroinvertébrés benthiques d'eau douce du Québec, 2010: Surveillance volontaire des cours d'eau peu profonds. Direction du suivi de l'état de l'environnement, ministère du Développement durable, environnement et parcs Québec.

[18] Tachet, H., Richoux, P., Bournaud, M. and Usseglio-Polatera, P. (2000) Invertébrés d'eau douce: Systématique, biologie, écologie. CNRS Ed.

[19] McCafferty, P.W. (1981) Aquatic Entomology. The Fisherman's and Ecologists' Illustrated. Guide to Insects and Their Relatives. Jones and Bartlett Publishers, Boston, London.

[20] R Core Team (2018) R: A Language and Environment for Statistical Computing. R Foundation for Statistical Computing, Vienna.

[21] Hammer, Ø., Harper, D.A.T. and Ryan, P.D. (2001) Paleontological Statistics Software: Package for Education and Data Analysis. Palaeontol. Electron.

[22] Zinsou, H.L., Attingli, A.H., Gnohossou, P., Adandedjan, D. and Lalèyè, P.A. (2016) Caractéristiques physico-chimiques et pollution de l'eau du delta de l'Oueme au Benin. Journal of Applied Biosciences, 97, 9163-9173. 
https://doi.org/10.4314/jab.v97i1.3

[23] Guigemdé, I., Zongo, F., Kabré, G., Nacoulma, P. and Senghor, A. (2003) Impact des eaux usées industrielles de Kossodo sur le bassin du Massili: Etude chimique, biologique et socio-économique-Projet de Recherche-CEPAPE-Univ. Ouaga.

[24] IBGE (2005) IBGE (Institut Bruxellois pour la Gestion de l'Environnement), Qualité physico-chimique et chimique des eaux de surface: Cadre général.

[25] Koudenoukpo, Z.C., Chikou, A., Adandedjan, D., Hazoume, R., Youssao, I., Mensah, G.A. and Laleye, P. (2017) Caractérisation physico-chimique d'un système lotique en région tropicale: la rivière Sô au Sud-Bénin, Afrique de l'Ouest. Journal of Applied Biosciences, 113, 11111-11122. https://doi.org/10.4314/jab.v113i1.1

[26] Buhungu, S., Montchowui, E., Barankanira, E., Sibomana, C., Ntakimazi, G. and Bonou, C.A. (2018) Caractérisation spatio-temporelle de la qualité de l'eau de la rivière Kinyankonge, affluent du Lac Tanganyika, Burundi. International Journal of Biological and Chemical Sciences, 12, 576-595. https://doi.org/10.4314/ijbcs.v12i1.44

[27] Arimoro, F.O., Odume, O.N., Uhunoma, S.I. and Edegbene, A.O. (2015) Anthropogenic Impact on Water Chemistry and Benthic Macroinvertebrate Associated Changes in a Southern Nigeria Stream. Environmental Monitoring and Assessment, 187, 14. https://doi.org/10.1007/s10661-014-4251-2

[28] Chapman, D.V. (1996) Water Quality Assessments: A Guide to the Use of Biota, Sediments and Water in Environmental Monitoring. CRC Press, Boca Raton. https://doi.org/10.4324/NOE0419216001

[29] BE (2012) Bruxelles Environnement. Programmes de surveillance de l'état des eaux de la Région de Bruxelles-Capitale en application de l'Ordonnance Cadre Eau.

[30] Ifremer (2000) Mise à jour d'indicateurs du niveau d'eutrophisation des milieux lagunaires méditerranéens-Rapport final-09-2000, Tome I-236 p, Tome II-196 p.

[31] Diomandé, D., Bony, Y.K., Edia, E.O., Konan, K. and Gourene, G. (2009) Diversité des Macroinvertébrés Benthiques de la Rivière Agnéby (Côte d'Ivoire; Afrique de l'Ouest). European Journal of Scientific Research, 35, 368-377.

[32] Wetzel, R.G. (2001) Limnology: Lake and River Ecosystems. 3rd Edition, Academic Press, San Diego.

[33] WHO (2017) Guidelines for Drinking-Water Quality: Fourth Edition Incorporating the First Addendum.

[34] Alhou, B., Issiaka, Y., Awaiss, A. and Micha, J.-C. (2014) Premier inventaire des macro-invertébrés du fleuve Niger à Niamey comme bioindicateurs de la pollution urbaine et industrielle. Hydroécologie Appliquée, 18, 139-163.

https://doi.org/10.1051/hydro/2014002

[35] Sanogo, S., Kabré, T.J.A. and Cecchi, P. (2014) Inventaire et distribution spatio-temporelle des macroinvertébrésbioindicateurs de trois plans d'eau du bassin de la Volta au Burkina Faso. International Journal of Biological and Chemical Sciences, 8, 1005-1029. https://doi.org/10.4314/ijbcs.v8i3.16

[36] Kabré, T.A., Illé, A. and Guenda, W. (2000) Inventaire et étude de la densité de distribution des insectes du benthos des deux lacs de barrage de Bagré. Revue Sciences et Techniques, Série Science Naturelle et Agronomie, 24, 121-132.

[37] OrouPiami, Z. (2018) Diversité et distribution spatiale des macroinvertébrés benthiques de la rivière Sota au Bénin. Mémoire pour l'obtention du Diplôme de Master Recherche de l'Ecole Doctorale des Sciences Agronomiques et de l'eau de l'Université de Parakou, Bénin. 
[38] Fu, L., Jiang, Y., Ding, J., Liu, Q., Peng, Q.-Z. and Kang, M.-Y. (2016) Impacts of Land Use and Environmental Factors on Macroinvertebrate Functional Feeding Groups in the Dongjiang River Basin, Southeast China. Journal of Freshwater Ecology, 31, 21-35. https://doi.org/10.1080/02705060.2015.1017847

[39] Nuamah, L.A., Huang, J. and Dankwa, H.R. (2018) Biological Water Quality Assessment of Shallow Urban Streams Based on Abundance and Diversity of Benthic Macroinvertebrate Communities: The Case of Nima Creek in Ghana. Environment and Ecology Research, 6, 93-101. https://doi.org/10.13189/eer.2018.060201

[40] Pan, B., Wang, Z., Yu, G., Xu, M., Zhao, N. and Brierley, G. (2013) An Exploratory Analysis of Benthic Macroinvertebrates as Indicators of the Ecological Status of the Upper Yellow and Yangtze Rivers. Journal of Geographical Sciences, 23, 871-882. https://doi.org/10.1007/s11442-013-1050-6 